\title{
The cause and mechanism of the fatal flood in Eleftheres, Kavala, Northern Greece
}

\author{
D. Emmanouloudis ${ }^{1} \&$ M. Kaikis ${ }^{2}$ \\ ${ }^{1}$ Department of Forestry and Natural Environment Management, \\ Technological Educational Institute of Kavala, Drama, Greece \\ ${ }^{2}$ Rhodes Municipal Environmental Organisation, Greece
}

\begin{abstract}
On 17 November 1992, after a brief $(\mathrm{t}<30 \mathrm{~min})$ but very heavy rainfall, the small torrents (four in all) flowing across the community of Eleftheres, Kavala, Northern Greece, flooded and caused extensive and intense flood disasters. It should be stressed that a few months earlier (August 1992), a ravaging fire had totally deforested the area of the drainage basins of the above torrents. The largest torrent, with a surface area of only $0.91 \mathrm{~km}^{2}$, formed a huge debris flow which moved in waves downwards, at first in the bed and then out of it, flooding the village of Eleftheres and, sweeping everything away, it demolished houses and almost buried the village in mud. As a result of this activity, three people were killed, dozens of others were injured and all the local activities were suspended for a period of several months. The torrent in question had never before operated as a debris flow torrent, nor had any landslides or similar geological phenomena causing debris flow occurred in its basin. The present paper studies the causes and the mechanism of the formation of debris flow of peculiar origin in this particular torrent and attempts to provide an interpretation of the phenomenon of the formation of debris flow in a torrent bed without an obvious cause, such as pre-flood feeding of the bed.
\end{abstract}

Keywords: deforestation, fatal flood, debris flow.

\section{Introduction}

Debris flow is a very important and famous geological phenomenon. Many researchers all over the world have studied the debris flow dynamics and process 
and many different theories have been formulated on its nature and characteristics. The number of papers published on the subject is so high that there have been researchers Davis [3] whose papers were an exclusive attempt to classify debris flow according to type on the basis of the internationally reported available descriptions of such phenomena.

This is the reason why the present paper does not intend to present once more some view on the nature and the characteristics of debris flow, but the causes and the mechanism of formation of a specific debris flow of peculiar origin, which, moving at first in the bed and then out of it, flooded the village of Eleftheres, demolished houses and almost buried it in mud.

The peculiar character of the origin of the above-mentioned debris flow was what prompted us to investigate the case of the torrent of Eleftheres. More specifically:

It is a well-known fact from the international bibliography Bull [2], Allen [1] that debris flow is formed in a torrent bed when the bed is fed with huge quantities of load in a very short time, as a consequence of the combined action of extraordinary climatic and geological factors, such as melting of glaciers, rupture of geological base due to seismic activity and subsequent torrential rains, abrupt or considerable landslides, etc. In this case, however, none of the abovementioned usual extraordinary phenomena had occurred in the drainage basin of the torrent. Thus, the unusual yet existing causes of formation of the debris flow in the torrent of Eleftheres had to be investigated, and interpretations had to be provided on the future behaviour of the torrent. All this constitutes the purpose of this paper.

\section{Field area}

The village of Eleftheres is situated in the region of Macedonia, Northern Greece, near the town of Kavala (Fig. 1).

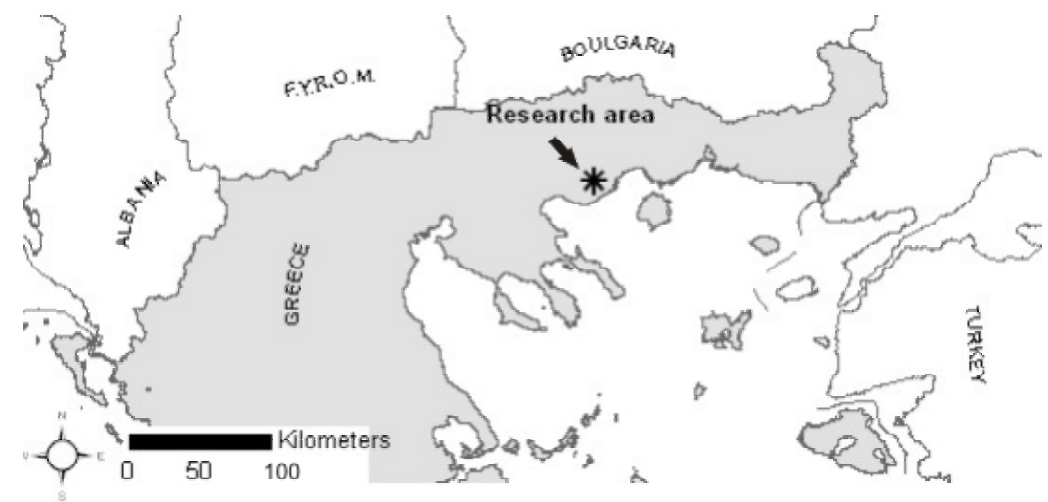

Figure 1: The location of the field area in the Greek territory. 
The present paper's field area is the mountainous area over Eleftheres and, more specifically, the drainage basin of the largest of the four torrents flowing through the village in question (Fig. 2).

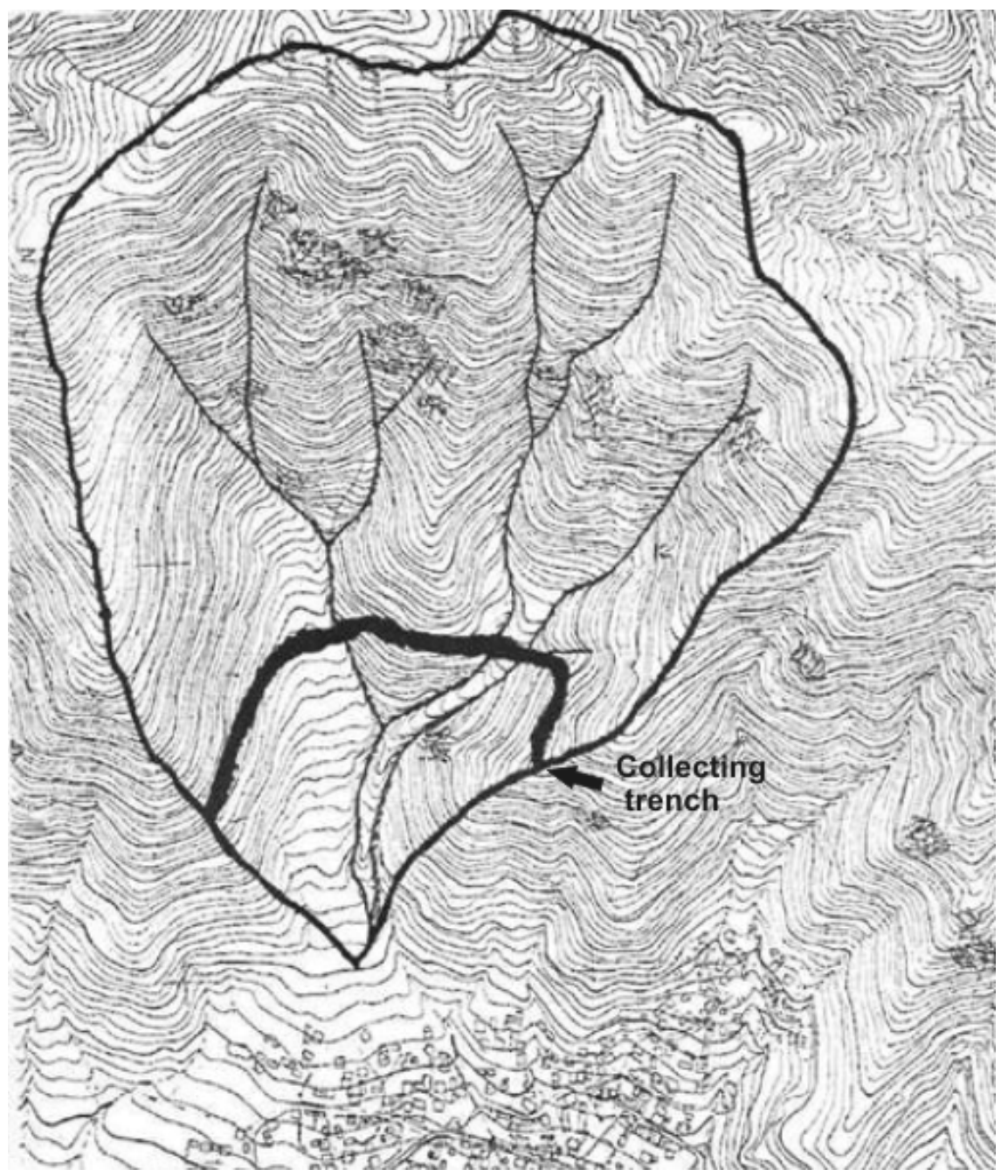

Figure 2: The drainage basin of the torrent of Eleftheres and the collecting trench.

Table 1 gives briefly the morphometric characteristics of the above basin, and table 2 shows the average monthly and yearly precipitation depths as provided by the weather stations near the field area.

The basin's vegetation before the fire consisted almost exclusively of Quercus pubescens, and of certain Salix individuals that appeared in the bed. Finally, the geological base of the area is granite. 
Table 1: $\quad$ Morphometric characteristics of the drainage basin.

\begin{tabular}{|c|c|c|c|c|c|c|c|}
\hline $\begin{array}{c}\text { Drainage } \\
\text { basin }\end{array}$ & $\begin{array}{c}\text { Area } \\
\mathrm{F} \\
(\mathrm{km})^{2}\end{array}$ & $\begin{array}{c}\text { Altitudes } \\
\text { Hmax } \\
(\mathrm{m})\end{array}$ & $\begin{array}{c}\mathrm{Hmin} \\
(\mathrm{m})\end{array}$ & $\begin{array}{c}\mathrm{DH} \\
(\mathrm{m})\end{array}$ & $\begin{array}{c}\text { Hmd } \\
(\mathrm{m})\end{array}$ & $\begin{array}{c}\text { Mean } \\
\text { basin } \\
\text { gradient } \\
(\%)\end{array}$ & $\begin{array}{c}\text { Mean } \\
\text { bed } \\
\text { gradient } \\
(\%)\end{array}$ \\
\hline Elefthere & 0.91 & 550 & 78 & 472 & 224 & 64 & 38.3 \\
\hline
\end{tabular}

Table 2: $\quad$ Weather data from the Station of Kavala Airport Period 19721980 .

\begin{tabular}{|c|c|c|c|c|c|c|c|c|c|c|c|c|c|}
\hline & & JAN & FEB & MAR & APR & MAY & JUN & JUL & AUG & SEP & $\mathrm{OKT}$ & $\mathrm{NOV}$ & $\overline{\mathrm{DEC}}$ \\
\hline 辰会 & MAX & 7.2 & 10.2 & 13 & 17.2 & 22.3 & 27.0 & 28.9 & 28.2 & 25.8 & 19.8 & 14.3 & 9.1 \\
\hline 岕 & MIN & 0.6 & 2.4 & 3.9 & 7.7 & 13.2 & 16.4 & 18.1 & 16.9 & 14.0 & 8.9 & 4.9 & 3.8 \\
\hline 学㲾 & AVER. & 3.8 & 6.4 & 8.9 & 12.8 & 18.3 & 22.7 & 24.7 & 23.5 & 20.9 & 15.1 & 9.6 & 4.9 \\
\hline 光 & MAX & 8.8 & 9.3 & 9.9 & 11.6 & 14.9 & 17.4 & 19.2 & 18.3 & 16.1 & 14.9 & 11.9 & 12.5 \\
\hline 岂司 & MIN & 1.9 & 2.8 & 3.1 & 5.4 & 7.3 & 9.0 & 10.0 & 9.3 & 6.8 & 4.1 & 3.1 & 3.9 \\
\hline 足罗 & AVER. & 5.2 & 6.5 & 6.9 & 9.2 & 12.2 & 14.2 & 15.5 & 14.5 & 12.0 & 10.0 & 7.8 & 6.1 \\
\hline RAII & $\begin{array}{l}\text { NFALL } \\
\text { A.M. }\end{array}$ & 54.3 & 57.8 & 33.4 & 65.4 & 48.5 & 36.3 & 46.0 & 32.0 & 25.7 & 60.1 & 61.9 & 62.3 \\
\hline $\begin{array}{r}\text { REL } \\
\mathrm{H}\end{array}$ & $\begin{array}{l}\text { AIR. } \\
\text { UM. }\end{array}$ & 77.0 & $\begin{array}{c}75 . \\
0\end{array}$ & $\begin{array}{c}72 . \\
0\end{array}$ & 71.0 & 690. & 66.0 & 63.0 & 64.0 & 64.0 & 72.0 & 77.0 & 78.0 \\
\hline
\end{tabular}

\section{Origin and formation of the debris flow in the field area}

\subsection{Origin}

On the basis of our current knowledge Johnson [7], Jian-Li and Defu [6], in order for debris flow to occur in the bed of a torrent, two basic factors have to be present:

1. The bed has to be fed with large quantities of load in a very short time.

2. The geomorphological conditions in the basin and the hydraulic conditions in the bed of the torrent have to be such as to permit the downward movement of the load.

In the case of the torrent studied in the present paper, the latter factor was evident at a glance, while the former was the object of wonder, since, as already stated, there was no obvious cause prior to the flood, such as feeding of the bed with enormous quantities of debris. 
Thus, after the field investigation which was conducted right after the flood and the analysis of the data, we reached the following conclusions on the subject of the first factor:

In the field area (Photo 1), in accordance with our observations and the accounts of the local inhabitants, neither any landslides had been recorded in the past, nor any other slide activity; moreover, the geological base being granite as it was, it was preventing rather than fostering the occurrence of similar phenomena, which are mostly observed in schist or flysch basins, etc. Kotoulas [8]. Moreover, no seismic activity had been recorded in the region in the past 100 years. The sole phenomenon that occurred in the area was the fire that had burnt it down a few months before the flood.

Thus, the most strikingly obvious fact since the first moment of our visit in the basin was the very intense erosion and the eluviation of a rich layer of soil that existed in it, as well as the very intense fragmentation of the rock (Fig. 3). But what had caused such an intense soil development on the one hand and the fragmentation of the non - disintegrated rock on the other?

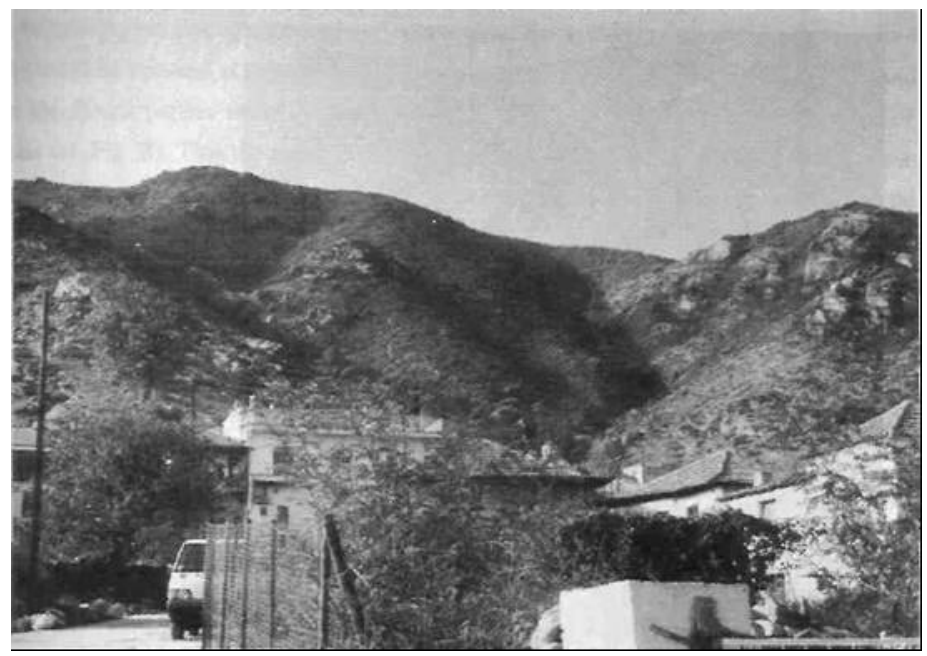

Figure 3: The position of the drainage basin with regard to the village.

Research carried out in Greece Polyzogopoulos [11], Papamihos [10] demonstrated that Quercus pubescens, which was the dominant plant variety in the basin prior to the fire, with a density of $100 \%$ at that, has a root system remarkably able to penetrate the underlying rock (by way of compressor). Once the root has entered the rock, it starts ramifying. The penetration and ramification of the root system causes a very intense fragmentation of the rock, which then undergoes intense disintegration, due to the special climatic and soil conditions prevailing in the Mediterranean countries Genny [5].

The above phenomenon, i.e. the presence of fragmented rock and abundant soil material, was observed in at least 3 other cases in the past 5 years in Greece 
(Thassos 1985, 1989, Fourka 1991) in torrent drainage basins which had all suffered disastrous fires before that, and whose forest cover consisted exclusively in Quercus. In all three cases, the fragmented rock and the soil material moved downwards after a rainfall and caused flood effects. The strange thing was that in all three cases considerable floods and occurrence of debris flow were only recorded the first time there were heavy rainfalls in the respective basin regions following the fires, while subsequent heavier and more intense rainfalls in the years that followed did not produce flood effects of equal importance to those of the first rainfall after the fire.

Thus, our observations in the basin of Eleftheres, as well as the information provided by the rest of the above-mentioned basins, have led us to the following conclusion as far as the origin of the debris in the basin in question is concerned:

Figure 4: Fragmented and intensely disintegrated granite in the drainage basin. Stones readily detachable can be seen.

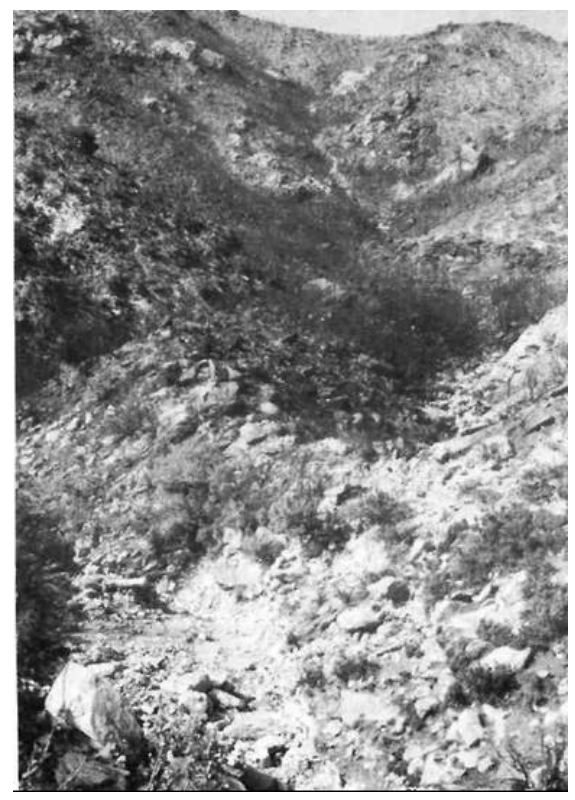

The presence of a very thick vegetation of Quercus pubescens in the drainage basin for over 200 years (data from the Forest Inspection Service of Kavala) resulted in the fragmentation of the underlying granite, which was already altered anyway Maratos [9] and very old.

The fragmented granite also underwent disintegration processes, which were further facilitated by the fact that granite is a rock easily flecked.

In this way, abundant, loose and "ready-to-move" load was produced in the basin. The load was of various grades, both rough (originating from fragmentation) and fine (originating from soil formation processes). This load 
was mixed in the position of production. Moreover, after the fire which burnt down the Quercus that was both producing and protecting it, it was fully exposed to the draining capacities of the rain.

However, it was not only the Quercus and the fire that contributed to the production of material that could be transported through the bed and, consequently, to debris flow formation; it was man himself, too. It should be stressed at this point that in September 1992 (one month after the fire and two months before the flood) parties from the community of Eleftheres dug a ditch in the lines of the contour intervals (cf. Fig. 2). This ditch, according to their estimates, would be capable of draining the waters that would flow from smaller torrent beds to the central one. Of course, not only this did not happen, but also the excavations from the ditch cutting (which remained unfinished, it should be noted) were "used" by rain water to enrich the load that was mobilized in the bed. This resulted in a combination of fine and rough load from three different origins (Fig. 5).
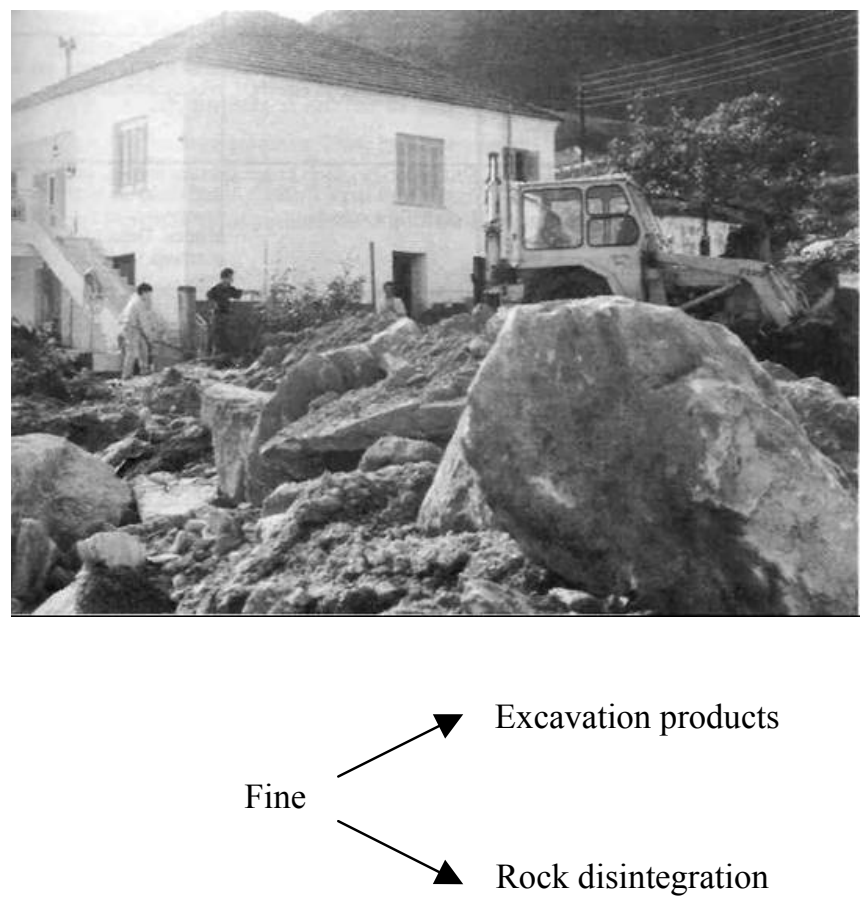

Rough $\longrightarrow$ rock fragmentation

Figure 5: Debris deposited in the village. The grades of the load can be seen. 


\subsection{Formation}

As far as the second indispensable factor for the occurence of debris flow is concerned, one can easily notice (cf. Table 1) that not only the average bed gradient, but also the average gradient of the basin in question are high, this combined effect creating a high torrential potential Emmanouloudis [4], i.e. increased possibilities for the load moving from the basin to the central bed at first, and then, through the bed, downwards to the torrent outlet, at the gorge of which the village is located.

On the basis of the above and given the fact that the area of the drainage basin is limited, it is easy to understand that even a moderate rainfall in terms of intensity and heaviness would suffice for the loose material to move downwards. And this was exactly the case; according to the accounts of the inhabitants*, the rainfall that caused the draining and the consequent movement of the brought material as well as the flood phenomenon did not last longer than $30 \mathrm{~min}$.

The study of the deposit layers of the debris flow in the area of the village and the descriptions of the inhabitants, (there is no Weather Station in the region), have led us to the conclusion that the excavation and disintegration products were eroded, swept away and carried by the rain water in stages, as follows:

Table 3: $\quad$ Mobilization of brought material in the torrent basin and bed.

\begin{tabular}{|c|c|c|c|}
\hline Stages & Movement on the slopes & $\begin{array}{l}\text { Movement in the } \\
\text { small beds }\end{array}$ & $\begin{array}{l}\text { Movement in the } \\
\text { central bed }\end{array}$ \\
\hline A & $\begin{array}{l}\text { The soil and excavation } \\
\text { material starts moving } \\
\text { towards the small beds }\end{array}$ & & \\
\hline B & $\begin{array}{l}\text { The soil and excavation material } \\
\text { is continuously eluviated. The } \\
\text { fragmented large stones attached } \\
\text { to the soil material start losing } \\
\text { their balance. }\end{array}$ & $\begin{array}{l}\text { Soil and excavation } \\
\text { material } \\
\text { with small stones } \\
\text { Solid } \\
\text { effects. }\end{array}$ & $\begin{array}{l}\text { Soil and excavation } \\
\text { material. Floating and } \\
\text { solid mobilization effects. }\end{array}$ \\
\hline $\mathrm{C}$ & $\begin{array}{l}\text { The soil and excavation } \\
\text { material has been fully } \\
\text { eluviated. The large rocks } \\
\text { without support on the slopes } \\
\text { move towards the small beds. }\end{array}$ & $\begin{array}{l}\text { Soil and excavation } \\
\text { material mixed with } \\
\text { large stones. Debris } \\
\text { flow effects }\end{array}$ & $\begin{array}{l}\text { Small stones, soil material } \\
\text { and excavation products. } \\
\text { Occurence of the first } \\
\text { large stones. Debris flow } \\
\text { effects starting. }\end{array}$ \\
\hline $\mathrm{D}$ & $\begin{array}{l}\text { Almost total absence of soil } \\
\text { material. Even larger stones start } \\
\text { moving downwards. }\end{array}$ & $\begin{array}{l}\text { Mostly large stones } \\
\text { and not as much fine } \\
\text { load. Debris Qow } \\
\text { effects. }\end{array}$ & $\begin{array}{l}\text { Soil material and } \\
\text { excavation products mixed } \\
\text { with large stones. Debris } \\
\text { flow effects. }\end{array}$ \\
\hline $\mathrm{E}$ & $\begin{array}{l}\text { Static equilibrium on the } \\
\text { surface of the slopes. }\end{array}$ & $\begin{array}{l}\text { Individual articles are } \\
\text { moving. Individua } \\
\text { solid mobilization. }\end{array}$ & $\begin{array}{l}\text { Large stones and not as } \\
\text { much fine load. Debris } \\
\text { flow effects. }\end{array}$ \\
\hline $\mathrm{F}$ & $\begin{array}{l}\text { Static equilibrium on the } \\
\text { surface of the slopes. }\end{array}$ & $\begin{array}{l}\text { Few solids are } \\
\text { moving. }\end{array}$ & $\begin{array}{lr}\text { Return to } & \text { solid } \\
\text { mobilization } & \text { state. } \\
\text { Movement ceases } & \\
\text { Gradually. } & \end{array}$ \\
\hline
\end{tabular}


Of course, it is easily understood that, had there been a new rainfall in the basin a few months later, even a much heavier one in terms of intensity, the brought material it would mobilize would be far less considerable, because there would have been no load in the position of production, since most of it would have been mobilized by the first rainfall.

This explains the fact that torrents of this kind (Thasos, Fourka, Eleftheres) do not present debris flow again in the future, or that they have not presented it in the past.

The brought material that moved downwards according to stages $\mathrm{C}$ on the table was the one that flooded the village of Eleftheres. Taking into consideration the position of the village with regard to the basin (cf. Photo 1), it is easily understood why houses were destroyed and why people drowned, especially when no protective works had been constructed nor had there been any torrent management.

\section{Conclusions}

The facts stated above, resulting from observations and investigation of the research field, lead to the following conclusions:

There may be more causes for the occurrence of debris flow in torrent beds, apart from those related to landslides, etc. These causes are the combined presence of certain kinds of vegetation in a basin for a series of years and its subsequent destruction from fire. The first heavy rainfall after the fire feeds the torrent bed with thousands of cubic meters of brought material. Subsequent rainfalls in this kind of torrents do not have the same effect, since the material has already been mobilized by the first rainfall. In this sense, these torrents can be described as unique debris flow torrents. This means that the behaviour of such torrents is similar to that of the normal ones, but once and only once they can operate as debris flow torrents. This, however, is predictable, since it only happens after a fire in the basin. Thus, in case the vegetation is totally destroyed in such torrents, there should be immediate action and the competent authorities should be alert to prevent disasters.

\section{References}

[1] Allen, R., Physical Processes of sedimentation, pp. 64-68, 1976.

[2] Bull, W., Alluvial fan deposits in Western Fresno County, California, Journal of Geology, Vol. 71, No 2, pp. 243-251, 1964.

[3] Davis, T., Debris flow surge, ETH, Zurich, 1988.

[4] Emmanouloudis, D., Mean bed slope and mean watershed slope. A combined factor of long-term torrential activity. IUFRO Centennial Meeting, 1992, Berlin, Germany. 1992,

[5] Genny, H., Factors of soil formation, McGraw-Hill, New York, 1981.

[6] Jian-Li \& Defu L., The formation and characteristics of mudflow and flood in the mountain area of the Da-Chao River and its Prevention, Zeitschrift fiir Geomorphologie B25, H4, 1981. 
204 Monitoring, Simulation, Prevention and Remediation of Dense and Debris Flows

[7] Johnson A., Mobilization of debris flows. Journal of Geomorphology, Supplement 9, pp.168-186, 1970.

[8] Kotoulas, D., Torrents in Northern Greece, Readership Thesis, GE.MEL.ER publication, 1970.

[9] Maratos, I., Geology of Greece, 1972.

[10] Papamihos, N., Forest Edaphology, AUT, Thessaloniki. 1978.

[11] Polyzogopoulos, N., Edaphology, AUT, Thessaloniki, 1976. 